\title{
Effects of sodium salicylate on glucose kinetics and insulin signaling in postpartum dairy cows
}

\author{
S. R. Montgomery, ${ }^{1}$ L. K. Mamedova, ${ }^{1}$ M. Zachut, ${ }^{2}$ G. Kra, ${ }^{2}$ S. Häussler, ${ }^{3}$ M. Vaughn, ${ }^{1}$ J. Gonzalez, ${ }^{1}$ \\ and B. J. Bradford ${ }^{1 *}$ \\ ${ }^{1}$ Department of Animal Sciences and Industry, Kansas State University, Manhattan 66506 \\ ${ }^{2}$ Agriculture Research Organization, Volcani Center, Rishon Lezion, Israel 7505101 \\ ${ }^{3}$ Institute of Animal Science, Physiology and Hygiene Unit, University of Bonn, Germany D-53012
}

\section{ABSTRACT}

Low-grade inflammation has been implicated as a contributor to metabolic disease during the transition to lactation. In previous work, administration of sodium salicylate (SS) for $7 \mathrm{~d}$ led to hypoglycemia in mature dairy cows in early lactation. The purpose of this study was to identify the mode of action underlying this response to SS. Twenty mature (parity 3) cows were assigned alternately at time of calving to either control or SS treatments; the control received a molasses placebo in drinking water, whereas SS received 2.3 $\mathrm{g} / \mathrm{L}$ of SS with the molasses carrier in drinking water for $7 \mathrm{~d}$ after parturition. Blood samples were collected daily. A glucose turnover assay was performed on d 7, followed by liver, muscle, and adipose tissue biopsies. There were no treatment effects on intake of dry matter or water. Tumor necrosis factor $\alpha$ mRNA abundance tended to be decreased by SS in adipose tissue but not in muscle or liver, and plasma haptoglobin and adiponectin concentrations were not altered by treatment. Treatment did not significantly alter plasma glucose or insulin concentrations, but plasma glucagon concentration tended to be increased by SS and the insulin: glucagon molar ratio was significantly decreased. Cows on SS had a tendency for a $25 \%$ decrease in glucose turnover rate compared with control cows. However, there were no differences in transcript abundance of pyruvate carboxylase (PC) or glucose-6-phosphatase (G6PC) in liver or of glucose transporter 4 (GLUT4) in any of the tissues. Finally, SS did not alter insulin receptor substrate-1 phosphorylation in muscle or adipose, but tended to increase phosphorylation of AMPactivated protein kinase and decrease protein kinase $\mathrm{B}$ phosphorylation in adipose tissue. These findings may be explained by enhanced hepatic insulin sensitivity

Received June 30, 2018.

Accepted November 5, 2018.

*Corresponding author: bbradfor@ksu.edu leading to posttranscriptional suppression of gluconeogenesis and adaptive responses to decreased glucose supply in the pancreas and adipose tissue.

Key words: transition cow, nonsteroidal antiinflammatory drug, insulin signaling, inflammation

\section{INTRODUCTION}

Dairy cows undergo a variety of physiological changes during the transition period, defined as $3 \mathrm{wk}$ before to 3 wk after calving (Grummer, 1995). These include endocrine changes associated with calving and metabolic changes due to a sudden increase in nutrient demands to synthesize milk (Drackley, 1999; Ingvartsen, 2006; Mulligan and Doherty, 2008). Apart from low blood glucose concentrations, postpartum cows often exhibit symptoms similar to type 2 diabetes, including elevated plasma free fatty acid concentrations (Contreras and Sordillo, 2011), liver lipid accumulation, and low-grade inflammation (Humblet et al., 2006; Bradford et al., 2015).

Both increased circulating fatty acid concentrations and chronic, low-grade inflammation have been linked to insulin resistance (IR) in humans and laboratory animals. Insulin resistance, the decreased sensitivity of tissue to the presence of insulin, plays a major role in the development of many metabolic health disorders in humans, including obesity, type 2 diabetes, hypertension, and cardiovascular disease (Kim et al., 2001). It is believed that high concentrations of plasma fatty acids interfere with insulin signaling in muscle by inhibiting phosphorylation of insulin receptor substrate (IRS) proteins, particularly IRS-1 (Morino et al., 2006; Park et al., 2007). Hepatic IR is believed to be linked to fatty acids impairing insulin-stimulated tyrosine phosphorylation of IRS-2 in humans (Morino et al., 2006). Moreover, it was demonstrated that adipose tissue is insulin resistant in cows with a high degree of lipolysis postpartum, whereas insulin signaling was intact in adipose of cows with a low degree of lipolysis (Zachut 
et al., 2013), consistent with the concept that high concentrations of plasma fatty acids (from lipolysis) interfere with insulin signaling. Combined with low circulating insulin concentrations in postpartum cows, these changes result in a substantial decrease in insulin signaling in early lactation compared with late gestation.

Inflammatory pathways including the NF- $\kappa \mathrm{B}$ pathway are also stimulated during the transition period and can impair metabolic functions (Sordillo and Raphael, 2013; Ringseis et al., 2015). There are several stimuli for this inflammation, including endoplasmic reticulum stress, high levels of circulating lipids, and infection (Hotamisligil, 2010). The role of inhibitor of nuclear factor kappa-B kinase subunit beta (IKK- $\beta$ ) is to activate NF- $\kappa \mathrm{B}$, which then stimulates an inflammatory response (Baker et al., 2011). Arkan et al. (2005) fed a high-fat diabetes-inducing diet to a set of mice that lacked IKK- $\beta$ enzymes in myeloid cells. Mice that lacked IKK- $\beta$ in myeloid cells were protected from systemic IR, suggesting that the NF- $\kappa$ B pathway is directly involved with lipid-induced IR (Arkan et al., 2005).

In dairy cows, reducing the effectiveness of insulin at the onset of lactation seems to facilitate the funneling of available glucose to the mammary gland to be used as energy for milk synthesis (Giesy et al., 2012), although the simple homeostatic mechanism of decreased insulin secretion is paramount in targeting nutrients to cells employing insulin-independent uptake mechanisms, such as mammary epithelial cells. Although this preferential partitioning of energy to the mammary gland ensures that the cow produces enough milk to support her calf, the diversion of almost $85 \%$ of the circulating glucose to the mammary gland contributes to the hypoglycemia often observed in transition cows (Sordillo et al., 2009).

One potential method to increase systemic insulin sensitivity is to mitigate inflammation. The administration of sodium salicylate (SS), a nonsteroidal anti-inflammatory drug, may decrease IR and minimize disruptive effects that inflammation may have on other metabolic processes. Sodium salicylate, though a weak cyclooxygenase inhibitor, has been shown to inhibit the NF- $\mathrm{BB}$ pathway by impairing the ability of IKK- $\beta$ to activate NF- $\kappa \mathrm{B}$ (Yin et al., 1998). In a previous study, SS administration for $7 \mathrm{~d}$ postpartum caused hypoglycemia, particularly in mature cows (3+ parity), by unknown mechanisms (Farney et al., 2013a). The purpose of this study was to investigate the mechanism behind this SS-induced hypoglycemia and to determine the extent to which SS alters glucose kinetics and insulin signaling in early postpartum dairy cows.

\section{MATERIALS AND METHODS}

\section{Animals, Treatments, and Care}

All procedures were approved by the Kansas State University Institutional Animal Care and Use Committee. Using published variance estimates (Waldron et al., 2006), we calculated that 10 cows per treatment would provide $80 \%$ power to detect a $0.41 \mathrm{~g} / \mathrm{h}$ change in glucose turnover, which was considered the primary outcome for this experiment.

Cows were housed in the Kansas State University Dairy Unit Tie-Stall Facility for the duration of the trial. Twenty mature cows (3rd parity) were enrolled 4 to $36 \mathrm{~h}$ after parturition and were alternately assigned to 1 of 2 treatments for $7 \mathrm{~d}$. Cows that experienced dystocia (calving difficulty score $\geq 3$ ) or had multiple births were not enrolled. Treatments were $2.3 \mathrm{~g} / \mathrm{L}$ of SS with a molasses carrier $(0.15 \mathrm{~g} / \mathrm{L})$ in the drinking water (SS treatment; $1.97 \mathrm{~g} / \mathrm{L}$ of salicylate), and control treatment of $0.15 \mathrm{~g} / \mathrm{L}$ of molasses in the drinking water $(\mathbf{C O N})$. Molasses was used to mask the flavor of SS and avoid negative effects on water intake.

Upon calving, all cows were given $500 \mathrm{~mL}$ of Milk Fever CP $(26 \% \mathrm{Ca}, 14 \%$ dextrose, $6 \% \mathrm{Mg}$ borogluconate, $0.5 \% \mathrm{P}$; Aspen Veterinary Resources Ltd., Liberty, MO) subcutaneously and $454 \mathrm{~g}$ of the electrolyte mixture Fresh Cow YMCP (12\% Ca, 11\% K, 5\% Mg, $2 \%$ $\mathrm{Na}, 0.6 \%$ niacin, $90 \mathrm{mg} / \mathrm{kg} \mathrm{Zn}, 882 \mathrm{kIU} / \mathrm{kg}$ of vitamin A, $176 \mathrm{kIU} / \mathrm{kg}$ of vitamin $\mathrm{D}, 882 \mathrm{IU} / \mathrm{kg}$ of vitamin E, $1.5 \times 10^{8} \mathrm{cfu} / \mathrm{g}$ of Saccharomyces cerevisiae; TechMix Inc., Stewart, MN) orally. One tube of CMPK Gel Plus ( $14 \% \mathrm{Ca}, 2.5 \%$ P, $0.75 \% \mathrm{Mg}, 0.5 \% \mathrm{~K}$; Vet Plus Inc., Menomonie, WI) was given orally once daily for the first $3 \mathrm{~d}$ postpartum. Urine ketones (ReliOn Ketone Strips, Walmart Inc., Bentonville, AR) and temperatures were monitored daily. Cows with high urinary ketone concentrations $(\geq 80 \mathrm{mg} / \mathrm{dL})$ for $1 \mathrm{~d}$ or moderate ketones (40-80 $\mathrm{mg} / \mathrm{dL}$ ) for 2 consecutive days were treated with Keto-gel (310 g/treatment; 94\% propylene glycol, $1.9 \%$ niacin, $1.9 \%$ choline, $1.6 \%$ methionine, 129 $\mathrm{IU} / \mathrm{g}$ of vitamin A, $32 \mathrm{IU} / \mathrm{g}$ of vitamin $\mathrm{D}, 0.32 \mathrm{IU} / \mathrm{g}$ of vitamin E; Jorgensen Labs, Loveland, CO) for $3 \mathrm{~d}$ at 7:00 h ( $\mathrm{n}=1 \mathrm{SS}, \mathrm{d} 5-7 ; \mathrm{n}=3 \mathrm{CON}, \mathrm{d} 3-5,4-6$, and 5-7, respectively). Cows exhibiting a temperature $>39.4^{\circ} \mathrm{C}$ were treated with Excenel RTU (Zoetis Animal Health, Florham Park, NJ) per label instructions ( $\mathrm{n}=2$ for SS and $\mathrm{n}=1$ for $\mathrm{CON}$ ). Cows diagnosed with a displaced abomasum before d 7 were removed from study, though all data collected before removal were used for analysis ( $\mathrm{n}=2$ for SS; removed on $\mathrm{d} 6$ and 7 , respectively). In total, 18 cows remained on study through the end of the study (10 CON and $8 \mathrm{SS})$. 
Table 1. Ingredient and nutritional composition of diet

\begin{tabular}{|c|c|}
\hline Item & Value \\
\hline \multicolumn{2}{|l|}{ Ingredient ( $\%$ of $\mathrm{DM})$} \\
\hline Corn silage & 11.9 \\
\hline Alfalfa hay & 13.4 \\
\hline Wet corn gluten feed ${ }^{1}$ & 33.0 \\
\hline Wheat straw & 3.6 \\
\hline Rolled corn & 13.4 \\
\hline Rolled milo & 8.4 \\
\hline Whole cottonseed & 5.0 \\
\hline Mechanically extracted soybean meal ${ }^{2}$ & 6.7 \\
\hline Ca salts of long-chain fatty acids ${ }^{3}$ & 0.8 \\
\hline Micronutrient premix ${ }^{4}$ & 3.6 \\
\hline \multicolumn{2}{|l|}{ Nutrient (\% of DM unless otherwise noted) } \\
\hline DM (\% as fed) & 50.1 \\
\hline $\mathrm{CP}$ & 17.4 \\
\hline NDF & 38.0 \\
\hline $\mathrm{ADF}$ & 23.6 \\
\hline $\mathrm{NE}_{\mathrm{L}}(\mathrm{Mcal} / \mathrm{kg})$ & 1.64 \\
\hline
\end{tabular}

${ }^{1}$ SweetBran (Cargill Inc., Blair, NE).

${ }^{2}$ Soy Best (Grain States Soya, West Point, NE).

${ }^{3}$ Megalac-R (Church \& Dwight Co., Princeton, NJ).

${ }^{4}$ Premix consisted of $42.5 \%$ limestone, $28.3 \%$ sodium bicarbonate, $4.7 \%$ magnesium oxide, $2.4 \%$ sodium chloride, $4.7 \%$ trace mineral salt, $4.7 \%$ vitamin E premix (44 IU/g), 0.5\% vitamin A premix $(30 \mathrm{kIU} / \mathrm{g})$, $0.1 \%$ vitamin D premix $(30 \mathrm{kIU} / \mathrm{g}), 0.7 \%$ 4-Plex (Zinpro Corp., Eden Prairie, MN; contains 2.58\% Zn, $1.48 \% \mathrm{Mn}, 0.90 \% \mathrm{Cu}, 0.18 \% \mathrm{Co}$, $8.21 \%$ Met, and $3.80 \%$ Lys), $0.7 \%$ selenium premix $(0.06 \%), 0.3 \%$ Zinpro 100 (Zinpro Corp.; contains 10\% Zn and 20\% Met), $0.03 \%$ ethylenediamine dihydroiodide premix $(44 \mathrm{mg} / \mathrm{g}), 0.6 \%$ Kallsil (Kemin Industries Inc., Des Moines, IA), 0.2\% Rumensin 90 (Elanco Animal Health; Greenfield, IN), 5.9\% XP Yeast (Diamond V, Cedar Rapids, IA), $2.9 \%$ biotin $(220 \mathrm{mg} / \mathrm{kg}$ ), and $0.6 \%$ Myco CURB (Kemin Industries Inc.).

Cows were milked 3 times daily $(0200,1000$, and 1800 h) and fed a TMR twice daily (0630 and $1600 \mathrm{~h}$ ) for ad libitum intake (Table 1). Feed and water intake were recorded daily. Body weight and BCS were recorded on d 1 and 9 postpartum.

\section{Procedures and Sample Collections}

Blood was collected into EDTA $(6 \mathrm{~mL})$ and sodium fluoride $(6 \mathrm{~mL})$ tubes (Vacutainer, Becton, Dickinson and Co., Franklin Lakes, NJ) from coccygeal vessels d 1 through $7(1500 \mathrm{~h})$. The samples were then immediately centrifuged at $2,000 \times g$ for $15 \mathrm{~min}$ at $22^{\circ} \mathrm{C}$, and plasma was collected and stored at $-20^{\circ} \mathrm{C}$ until analyzed.

On d 5, cows were fitted with a guidewire-style jugular catheter (Mila International Inc., Erlanger, KY). The catheter was flushed twice daily with $5 \mathrm{~mL}$ of a sterile solution of $3.5 \%$ sodium citrate to prevent clotting. On d 7, a glucose turnover assay was performed. Beginning with the morning feeding $(0630 \mathrm{~h})$, cows were fed $25 \%$ of their allotted morning ration every $2 \mathrm{~h}$ to promote steady-state metabolic conditions. At 1230 $\mathrm{h}, 1 \mathrm{~g}$ of $\mathrm{U}^{-13} \mathrm{C}$-glucose (99 atom \%, Sigma Chemical Co., St. Louis, MO) dissolved in $50 \mathrm{~mL}$ of saline was infused into the jugular vein catheter in a bolus dose, followed by a flush with $3.5 \%$ sodium citrate. Syringes containing $\mathrm{U}_{-}{ }^{13} \mathrm{C}$-glucose were weighed immediately before and after infusion to determine the exact amount administered. Jugular blood samples were collected into evacuated tubes containing sodium fluoride and potassium oxalate (Vacutainer, Becton, Dickinson and Co.) 10 min before infusion and at 10, 20, 30, 40, 50, 60,90 , and 120 min postinfusion.

Immediately after the completion of the glucose turnover assay, liver, muscle, and adipose tissue biopsies were performed. Liver samples were collected as described previously (Morey et al., 2011). Approximately $200 \mathrm{mg}$ of liver tissue was collected, snap-frozen in liquid nitrogen, and stored at $-80^{\circ} \mathrm{C}$ until analyzed.

For the adipose tissue biopsies, the area between the tailhead and pin bone was used. The area was clipped and scrubbed, and local anesthesia was applied (lidocaine hydrochloride, Agri Laboratories Ltd., St. Joseph, MO). A 3-cm-long incision was made with a \#22 blade (Feather Sterile Surgical Blade, GF Health Products Inc., Atlanta, GA). Subcutaneous adipose tissue was collected from the incision site with sterile forceps and surgical scissors. Approximately $5 \mathrm{~g}$ of tissue was collected, snap-frozen in liquid nitrogen, and stored at $-80^{\circ} \mathrm{C}$ until analysis. After tissue collection, the incision site was closed with surgical staples.

Muscle tissue biopsies were collected at the first lumbar vertebra. The area was aseptically prepared and a local anesthesia was given (lidocaine hydrochloride, Agri Laboratories Ltd.). A 12-gauge needle was used to initially breech the skin to allow the biopsy needle access to the muscle tissue. A 14-gauge, 9-cm-long biopsy needle (SABD-1409-15-T; US Biopsy, Franklin, IN) was inserted perpendicular to the orientation of the longissimus lumborum muscle fibers. Approximately $300 \mathrm{mg}$ of muscle tissue was extracted, snap-frozen in liquid nitrogen, and stored at $-80^{\circ} \mathrm{C}$ until analyzed.

\section{Plasma Analyses}

Plasma samples were analyzed for glucose (kit \#43990901, Wako Chemicals USA Inc., Richmond, VA), insulin (\#10-1201-01, Mercodia AB, Uppsala, Sweden), BHB (\#H7587-58, Pointe Scientific Inc., Canton, MI), fatty acids (NEFA-HR, Wako Chemicals USA Inc.), glucagon (\#GL-32K, Millipore, Billerica MA), tumor necrosis factor (TNFo; Farney et al., 2011), lactate (\#L7596-50; Pointe Scientific Inc.), haptoglobin (Cooke and Arthington, 2013), and adiponectin (Mielenz et al., 2013).

Glucose turnover assay samples were analyzed for total glucose concentration to ensure steady-state requirements were met and then were analyzed for $\mathrm{U}-{ }^{13} \mathrm{C}$ - 
glucose to determine the enrichment of plasma glucose (Metabolic Solutions Inc., Nashua, NH). Glucose was extracted and converted to aldonitrile pentaacetate derivative (Tserng and Kalhan, 1983), and negative chemical ionization GC/MS (Hewlett-Packard 5890) was used to analyze derivatized samples. The isotopic composition of the glucose was determined by monitoring unlabeled $(\mathrm{M}+0: \mathrm{m} / \mathrm{z}=328)$ versus $\mathrm{U}_{-}{ }^{13} \mathrm{C}$-labeled $(\mathrm{M}+6: \mathrm{m} / \mathrm{z}=334)$ glucose derivatives. Enrichment of plasma glucose for each animal was fitted to an exponential decay curve using the following equation: $\mathrm{E}_{\mathrm{t}}=$ $\mathrm{E}_{0} \times \mathrm{e}^{-\mathrm{kt}}$, where $\mathrm{t}=$ time relative to infusion (min), $\mathrm{E}_{\mathrm{t}}=$ enrichment of plasma glucose $\left(\mathrm{U}_{-}{ }^{13} \mathrm{C}\right.$-glucose: unlabeled glucose ratio) at time $t, \mathrm{E}_{0}=$ enrichment at time $\mathrm{t}=0$, and $\mathrm{k}=$ rate constant $\left(\mathrm{min}^{-1}\right)$. After using the best-fit equations to determine $\mathrm{k}$ and $\mathrm{E}_{0}$, the total glucose pool was calculated by this equation: $\mathrm{G}=\mathrm{M} \div$ $\mathrm{E}_{0}$, where $\mathrm{G}=$ total glucose pool $(\mathrm{g})$ and $\mathrm{M}=$ mass of tracer infused (g). Plasma glucose turnover rate (GTR; $\mathrm{g} / \mathrm{min}$ ) was calculated by the equation $\mathrm{GTR}=\mathrm{G} \times$ $\mathrm{k}$. Samples collected 10 min before infusion of $\mathrm{U}_{-}{ }^{13} \mathrm{C}-$ glucose were also analyzed to verify the lack of natural occurrence of the $\mathrm{M}+6$ isotopomer.

\section{Transcript Analysis}

Total RNA was isolated from all tissue types (RNeasy Lipid Tissue Mini Kit, Qiagen Inc., Valencia, CA) and RNA was quantified via spectroscopy (NanoDrop Technologies Inc., Wilmington, DE). A random subset of RNA samples was subjected to quality assessment (Bioanalyzer, Agilent Technologies, Santa Clara, CA), and mean $( \pm \mathrm{SD})$ RNA integrity numbers were $8.2 \pm$ 0.24 for liver samples, $6.5 \pm 0.43$ for muscle, and 4.56 \pm 0.51 for adipose tissue. Two micrograms of total RNA was used as template for the reverse transcriptase reaction using random primers (High-Capacity cDNA RT Kit, Applied Biosystems, Foster City, CA). Quantitative real-time PCR was performed in duplicate on 96 -well plates with $1 / 20$ of the cDNA product in the presence of $200 \mathrm{nmol} / \mathrm{L}$ of gene-specific forward and reverse primers with real-time SYBR green fluorescent detection using SYBR Green Premix reagent (7500 Fast Real-Time PCR System, Applied Biosystems). Gene targets, primers, and reaction efficiencies are listed in Table 2. All sample values were normalized against the geometric mean of RPS9, RPS15, and $A C T B \mathrm{C}_{\mathrm{t}}$ values and the results are expressed as fold change calculated using measured reaction efficiency: relative abundance $=\mathrm{E}_{\text {target }}{ }^{-\mathrm{Ct} \text { target }} \div \mathrm{E}_{\text {reference }}{ }^{-\mathrm{Ct} \text { reference }}$ (Pfaffl, 2001), where $\mathrm{E}=$ efficiency (expressed as copies generated per copy with each PCR cycle) and $\mathrm{Ct}=$ cycles to threshold.

\section{Western Blot Analyses}

For Western blot analysis, tissue samples $(\sim 20 \mathrm{mg})$ were lysed at $4{ }^{\circ} \mathrm{C}$ with radioimmunoprecipitation assay lysis buffer $(50 \mathrm{~m} M$ Tris- $\mathrm{HCl}, \mathrm{pH} 7.5,150 \mathrm{~m} M \mathrm{NaCl}$, $1 \%$ nonyl phenoxylpolyethoxylethanol- $40,0.5 \%$ sodium deoxycholate, and 0.1\% SDS; Santa Cruz Biotechnology, Santa Cruz, CA) containing an X1 broad-spectrum protease inhibitor cocktail (Protease Inhibitor Cocktail I, Calbiochem, Gibbstown, NJ) and PhosStop (Roche, Germany). Lysed samples were centrifuged at 15,000

Table 2. Primers used for quantitative real-time PCR detection

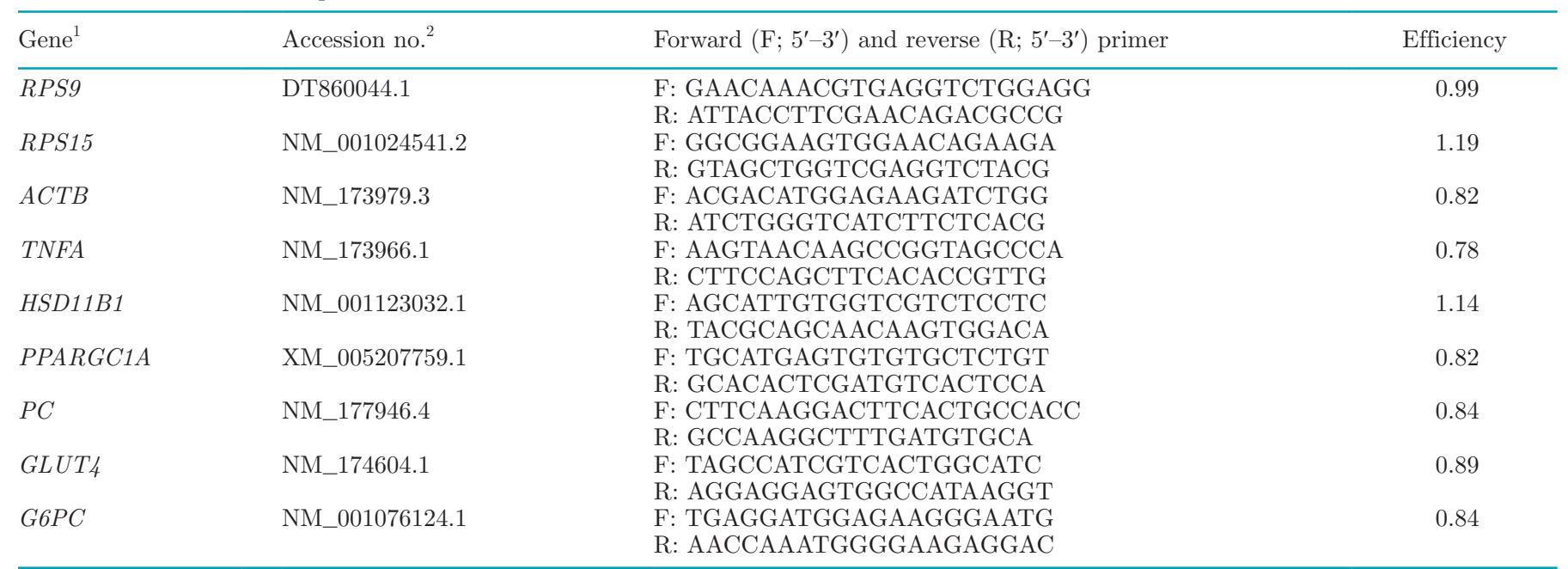

${ }^{1} R P S 9=$ ribosomal protein subunit $9 ; R P S 15=$ ribosomal protein subunit $15 ; A C T B=\beta$-actin; TNFA = tumor necrosis factor $\alpha ; H S D 11 B 1$ $=$ hydroxysteroid $11-\beta$ dehydrogenase $1 ; P P A R G C 1 A=$ peroxisome proliferator-activated receptor-gamma coactivator-1 $\alpha ; P C=$ pyruvate carboxylase; $G L U T 4=$ glucose transporter type 4; G6PC $=$ glucose-6-phosphatase .

${ }^{2}$ From National Center for Biotechnology Information Entrez Nucleotide Database (http://www.ncbi.nlm.nih.gov/nucleotide/). 
$\times g$ for $10 \mathrm{~min}$ at $4^{\circ} \mathrm{C}$ and total protein concentration of the supernatant was measured with a Coomassie protein assay kit (Pierce, Rockford, IL).

Proteins in the supernatant were denatured with SDS buffer containing dithiothreitol for $5 \mathrm{~min}$ at $95^{\circ} \mathrm{C}$. Forty micrograms of protein was loaded in each lane, and proteins were separated by using SDS-PAGE on a 4 to $12 \%$ Tris-glycine gel, and dry transferred onto nitrocellulose membranes (iBlot, Invitrogen, Thermo Fisher Scientific). Membranes were blocked in Tris-buffered saline $(10 \mathrm{~m} M$ Tris and $15 \mathrm{~m} M \mathrm{NaCl}, \mathrm{pH}$ 7.4) with $5 \%$ dry milk powder for $2 \mathrm{~h}$ at room temperature and then incubated overnight with the antibodies $(1: 1,000$ dilution; Santa Cruz Biotechnology): rabbit anti-IRS-1 (sc-559) or rabbit anti-pIRS-1 (Tyr 632; sc-17196). The secondary antibody, goat anti-rabbit IgG (sc-2004), was diluted 10,000-fold and incubated for $1 \mathrm{~h}$ at room temperature. All incubations were performed in Trisbuffered saline (pH 7.4) with $0.1 \%$ Tween 20 and $5 \%$ dry milk. Dry milk was not added for the final washing. Immunodetection was performed by using chemiluminescence (West-Dura, Thermo Scientific, Waltham, MA). Signal intensity was determined by densitometry (ChemiDoc-It Imaging System, UVP Inc., Upland, CA). Protein densitometry pixels were analyzed using ImageJ software (https://imagej.nih.gov/ij/; National Institutes of Health, Bethesda, MD).

For analysis of the adipose tissue AMP-activated protein kinase (AMPK) and protein kinase B (Akt) phosphorylation state, $20 \mu \mathrm{g}$ of sample in Laemmli loading buffer was resolved by SDS-PAGE under reducing conditions on a 4 to $12 \%$ Tris-glycine gel and transferred onto a nitrocellulose membrane for incubation with the following antibodies (Cell Signaling Technology, Danvers, MA): total AMPK (\#5832), phosphorylated AMPK (Thr172, \#2531), phosphorylated $\mathrm{Akt}_{473}$ (Ser473, \#9271), and total Akt (\#4691). Enhanced chemiluminescence was used for protein detection. To ensure that quantitative data were obtained, chemiluminescence signals were measured under at least 5 consecutive exposure times to determine the linear range of signal intensity of each antibody. Densitometry data were acquired using ImageJ software.

\section{Milk Analyses}

Milk yield was recorded daily and milk samples were collected at each milking on d 4 to 7 . Milk samples were analyzed for concentrations of fat, true protein, lactose (B-2000 Infrared Analyzer, Bentley Instruments Inc., Chaska, MN), urea nitrogen (MUN spectrophotometer, Bentley Instruments Inc.), and somatic cells (SCC 500, Bentley Instruments Inc.; Heart of America DHIA, Manhattan, KS). Somatic cell linear score (SCLS) was determined using the following equation: SCLS $=\log _{2}$ (SCC/100) + 3 (Schukken et al., 2003).

\section{Statistical Analysis}

Statistical analyses were carried out with the Mixed Procedure of SAS (version 9.3, SAS Institute Inc., Cary, NC). Results determined over time were modeled with the fixed effects of treatment, day, and treatment $\times$ day interaction as well as the random effect of cow. Repeated measures within cow were modeled with an autoregressive (AR[1]) covariance structure. Day 1 plasma samples were collected before treatments were applied, so d 1 values were used as a covariate for the analysis of plasma metabolites. For single time point variables, the model included the fixed effect of treatment and the random effect of cow. Adipose Akt phosphorylation data and all mRNA results other than adipose GLUT4 were natural log-transformed for statistical analysis to achieve normal residual distributions, and reported means were back-transformed (Bland and Altman, 1996). Outliers were identified and excluded from analysis when the studentized residual was $>3.5$ or $<-3.5$. Tendencies were declared at $0.05 \leq P<0.10$ and significance at $P<0.05$.

\section{RESULTS}

\section{Water and DMI}

No treatment $\times$ time interactions were observed for any parameter measured (all $P>0.15$ ), allowing us to focus on overall treatment effects. There was no treatment effect on DMI $(P=0.98 ; 13.38$ vs. 13.35 $\pm 0.99 \mathrm{~kg} / \mathrm{d}$ for CON and SS, respectively; Figure 1). There was also no treatment effect on water intake $(P$ $=0.61 ; 77.9$ vs. $73.9 \pm 5.6 \mathrm{~L} / \mathrm{d}$ for $\mathrm{CON}$ and SS, respectively), suggesting that any adverse taste of salicylate was effectively masked by the molasses added for both treatment groups (Figure 1). Mean water intakes were similar to those in a previous SS study (Farney et al., 2013a), which achieved therapeutic levels of SS using the same treatment protocol employed in this experiment.

\section{BW, BCS, and Milk Secretion}

Day $1 \mathrm{BCS}$ for $\mathrm{CON}$ and SS cows were $3.6 \pm 0.17$ and $3.5 \pm 0.16$, respectively, and d 9 BCS for CON cows was $3.29 \pm 0.16$ and $3.29 \pm 0.17$ for SS cows (treatment $P=0.76$; treatment $\times$ day $P=0.58$ ). There was no difference in BW between CON and SS treatments on d $1(776 \pm 21 \mathrm{~kg}$ vs. $777 \pm 22 \mathrm{~kg} ; P=0.97)$ or d 9 $(739 \pm 21 \mathrm{~kg}$ vs. $735 \pm 22 \mathrm{~kg} ; P=0.89)$. On average, 
Table 3. Milk production responses to $7 \mathrm{~d}$ of postpartum treatment with sodium salicylate (SS; $2.3 \mathrm{~g} / \mathrm{L}$ in drinking water) or control $(\mathrm{CON})$

\begin{tabular}{|c|c|c|c|c|c|}
\hline \multirow[b]{2}{*}{ Item $^{1}$} & \multicolumn{2}{|c|}{ Treatment } & \multirow[b]{2}{*}{ SEM } & \multicolumn{2}{|c|}{$P$-value } \\
\hline & $\mathrm{CON}$ & SS & & Treatment (Trt) & Trt $\times$ day \\
\hline Milk yield, $\mathrm{kg} / \mathrm{d}$ & 31.56 & 31.64 & 1.51 & 0.97 & 0.66 \\
\hline Milk fat, $\%$ & 5.26 & 5.78 & 0.34 & 0.29 & 0.21 \\
\hline Milk protein, \% & 3.58 & 3.84 & 0.09 & 0.05 & 0.74 \\
\hline SCLS $^{2}$ & 2.83 & 2.59 & 0.50 & 0.73 & 0.36 \\
\hline Milk lactose, \% & 4.34 & 4.35 & 0.10 & 0.77 & 0.89 \\
\hline MUN, mg/dL & 11.44 & 12.54 & 0.70 & 0.28 & 0.31 \\
\hline \multicolumn{6}{|l|}{ Yield, kg/d } \\
\hline Milk fat & 1.83 & 2.05 & 0.11 & 0.17 & 0.14 \\
\hline Milk protein & 1.29 & 1.35 & 0.09 & 0.59 & 0.30 \\
\hline Milk lactose & 1.59 & 1.55 & 0.11 & 0.77 & 0.34 \\
\hline $\mathrm{ECM}^{3}$ & 45.29 & 48.49 & 3.12 & 0.36 & 0.16 \\
\hline
\end{tabular}

${ }^{1}$ Values are LSM \pm SEM; $n=10$. Milk yield values represent $d 1$ to 7 ; all other data represent $\mathrm{d} 4$ to 7 .

${ }^{2}$ Somatic cell linear score $=\log _{2}(\mathrm{SCC} / 100)+3$ (Schukken et al., 2003).

${ }^{3} \mathrm{ECM}=(0.327 \times$ milk yield $)+(12.95 \times$ fat yield $)+(7.65 \times$ protein yield $)$.

cows lost $0.25 \pm 0.11 \mathrm{BCS}$ units and $40 \pm 15 \mathrm{~kg}$ of $\mathrm{BW}$ between $\mathrm{d} 1$ and 9 .

There was no treatment effect on milk yield, and milk fat, lactose, MUN, and SCLS were likewise similar across treatments (Table 3). Milk protein concentration
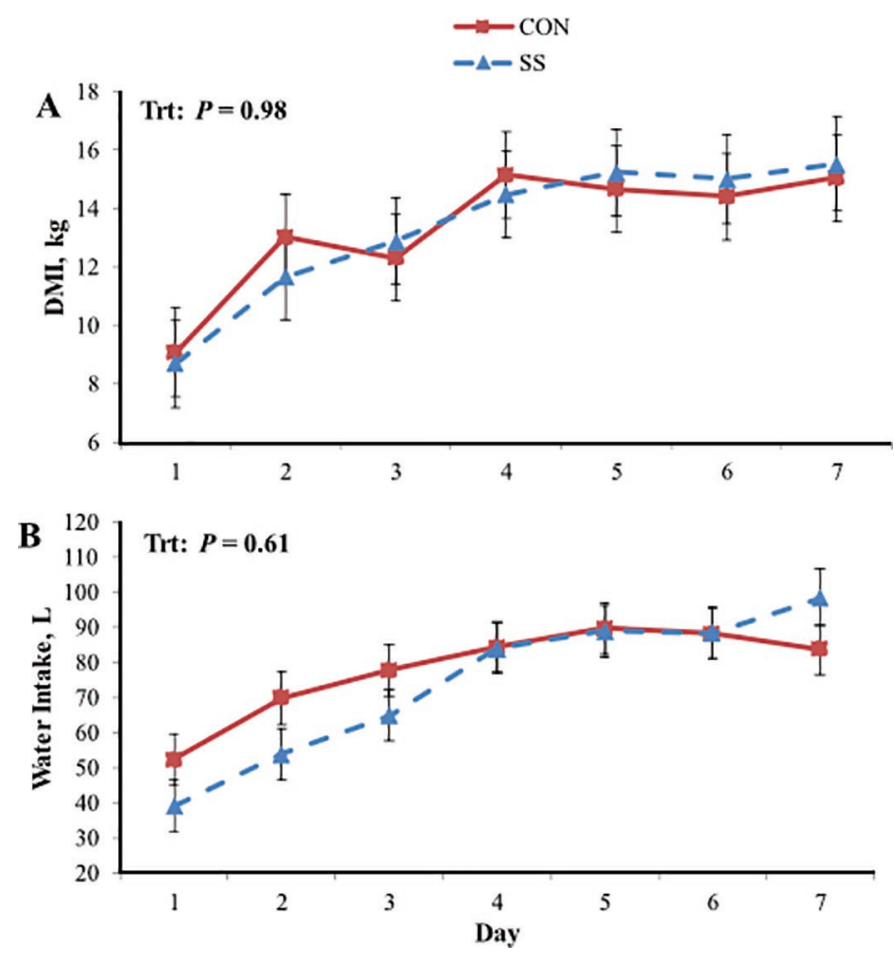

Figure 1. Postpartum intake of DM (A) and water (B) during the 7-d treatment period. Treatment with $2.3 \mathrm{~g} / \mathrm{L}$ of sodium salicylate in drinking water (SS) or control (CON) began approximately $24 \mathrm{~h}$ after calving and continued through $\mathrm{d} 7$ of lactation. No differences were observed in $\mathrm{DM}$ or water intake between treatments (treatment $\times$ day interactions: $P=0.86$ and 0.20 for $\mathrm{DM}$ and water intake, respectively). Values are $\mathrm{LSM} \pm \mathrm{SEM} ; \mathrm{n}=8-10$. Trt $=$ treatment. was greater in SS-treated cows compared with CON, but without a significant effect on milk protein yield (Table 3).

\section{Plasma Metabolites and Glucose Turnover Assay}

Plasma fatty acid, BHB, and lactate concentrations were unaffected by treatment (Table 4). Likewise, neither haptoglobin, an acute phase protein, nor TNF $\alpha$, a proinflammatory cytokine, were altered by treatment. Adiponectin, an adipose-derived hormone that promotes insulin sensitivity, was not affected by SS (Table 4).

Glucose concentrations were similar across treatments $(P=0.25$; Figure $2 \mathrm{~A})$, but plasma glucose turnover rate tended to be decreased by $25 \%$ in SS-treated cows $(P=$ 0.055; Figure 2B). This occurred without a significant treatment effect on plasma insulin concentration $(P=$ 0.13 ), although plasma glucagon concentration tended to be increased by SS treatment $(P=0.08$; Figure 3$)$. The insulin:glucagon molar ratio, used as an estimate of net endocrine influence on glucose metabolism, was decreased by SS $(P=0.01$; Figure 3$)$.

\section{Regulatory Protein Phosphorylation}

Insulin signaling was probed in muscle and adipose tissue through evaluation of tyrosine phosphorylation of IRS-1. Treatment did not affect total IRS-1 band densitometry in either tissue (both $P>0.72$ ). Relative tyrosine phosphorylation of IRS-1 in muscle was not affected by treatment (1.15 vs. $1.31 \pm 0.09$ for CON vs. SS, respectively; $P=0.25$ ). Likewise, adipose tissue did not show differential IRS-1 phosphorylation after SS treatment (Figure 4A). 

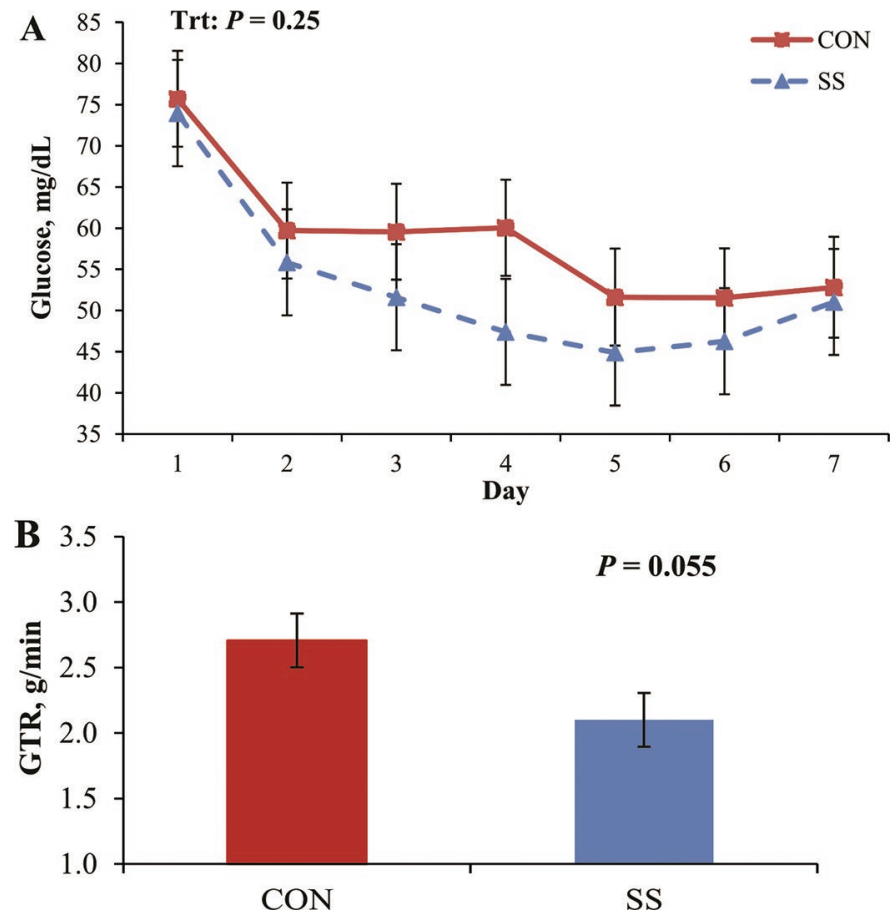

Figure 2. Postpartum glucose and glucose turnover rate responses to treatment. Treatment with $2.3 \mathrm{~g} / \mathrm{L}$ of sodium salicylate in drinking water (SS) or control (CON) began approximately $24 \mathrm{~h}$ after calving and continued through d 7 of lactation. (A) No treatment effect was observed on plasma glucose concentration $(P=0.25$; treatment $\times$ day, $P=0.72$ ). (B) Glucose turnover rate (GTR; $\mathrm{d} 7$ ), a measure of gluconeogenesis, tended to be decreased by SS $(P=0.055)$. Values are LSM \pm SEM; $\mathrm{n}=8-10$. Trt $=$ treatment.

We also investigated AMPK and Akt, 2 kinases that integrate nutrient signals downstream of the insulin receptor, in adipose tissue. Again, treatment had no effect on total abundance of these kinases (both $P>$ 0.59). The phosphorylation of AMPK (pAMPK/total AMPK) tended to be greater in SS than in control adipose tissue $(P<0.06$, Figure $4 \mathrm{~B})$, whereas the phosphorylation of Akt (pAkt/total AKT) in adipose tended to be decreased by SS $(P<0.08$, Figure $4 \mathrm{C})$.

\section{Transcript Abundance}

Tumor necrosis factor $\alpha$ mRNA abundance tended to be decreased by SS in adipose tissue but not in muscle or liver (Table 5). GLUT4 mRNA abundance was unaltered by SS treatment in these tissues. Progluconeogenic liver transcripts glucose-6-phosphatase $(G 6 P C)$, pyruvate carboxylase $(P C)$, and peroxisome proliferator-activated receptor-gamma coactivator-1 $\alpha$ (PPARGC1A) were not affected by treatment. Finally, 11ß-hydroxysteroid dehydrogenase type 1 (HSD11B1) mRNA, which encodes a cortisol-producing enzyme downregulated by salicylate in murine and human adipose tissue (Nixon et al., 2012), was unaffected by SS in the tissues we sampled (Table 5).

\section{DISCUSSION}

Hypoglycemia and associated metabolic disorders such as ketosis and fatty liver continue to be a significant problem in management of periparturient dairy cows (Lucy et al., 2014; Gordon et al., 2017). A transient insulin resistant state is thought to aid cows in providing glucose for mammary use by avoiding utilization of glucose for processes that can rely on other substrates, by preventing downregulation of gluconeogenesis, or both (Baumgard et al., 2017). Net uptake of glucose by the hind limb in response to hyperinsulinemia was decreased in lactating versus nonlactating ewes (Vernon et al., 1990), and both acetate incorporation into fatty acids and glucose utilization in the presence of insulin were decreased in adipose tissue excised from lactating versus nonlactating ewes (Vernon and Finley, 1988). Nevertheless, whether or not changes in insulin sensitivity are critical to homeorhetic adaptations to lactation (and the tissues that drive such a response) remains under investigation (Zachut et al., 2013; Weber et al., 2016).

The inflammatory tone of this cohort of cows appeared to align with the typical transition dairy cow.

Table 4. Plasma analyte responses to $7 \mathrm{~d}$ of postpartum treatment with sodium salicylate (SS; $2.3 \mathrm{~g} / \mathrm{L}$ in drinking water) or control (CON)

\begin{tabular}{|c|c|c|c|c|c|}
\hline \multirow[b]{2}{*}{ Item $^{1}$} & \multirow[b]{2}{*}{$\mathrm{CON}$} & \multirow[b]{2}{*}{ SS } & \multirow[b]{2}{*}{ SEM } & \multicolumn{2}{|c|}{$P$-value } \\
\hline & & & & Treatment (Trt) & Trt $\times$ day \\
\hline Adiponectin, $\mu \mathrm{g} / \mathrm{mL}$ & 4.70 & 3.98 & 1.74 & 0.77 & 0.37 \\
\hline $\mathrm{BHB}, \mu M$ & 875 & 1,004 & 89 & 0.32 & 0.94 \\
\hline Haptoglobin, $\mu \mathrm{g} / \mathrm{mL}$ & 395 & 537 & 102 & 0.34 & 0.11 \\
\hline Lactate, $\mu M$ & 384 & 420 & 50 & 0.61 & 0.78 \\
\hline Fatty acids, $\mu M$ & 998 & 963 & 70 & 0.37 & 0.11 \\
\hline $\mathrm{TNF} \alpha,{ }^{2} \mathrm{pg} / \mathrm{mL}$ & 75 & 90 & 15 & 0.50 & 0.33 \\
\hline
\end{tabular}

${ }^{1}$ Values are LSM \pm SEM; $\mathrm{n}=10$.

${ }^{2}$ Tumor necrosis factor $\alpha$. 

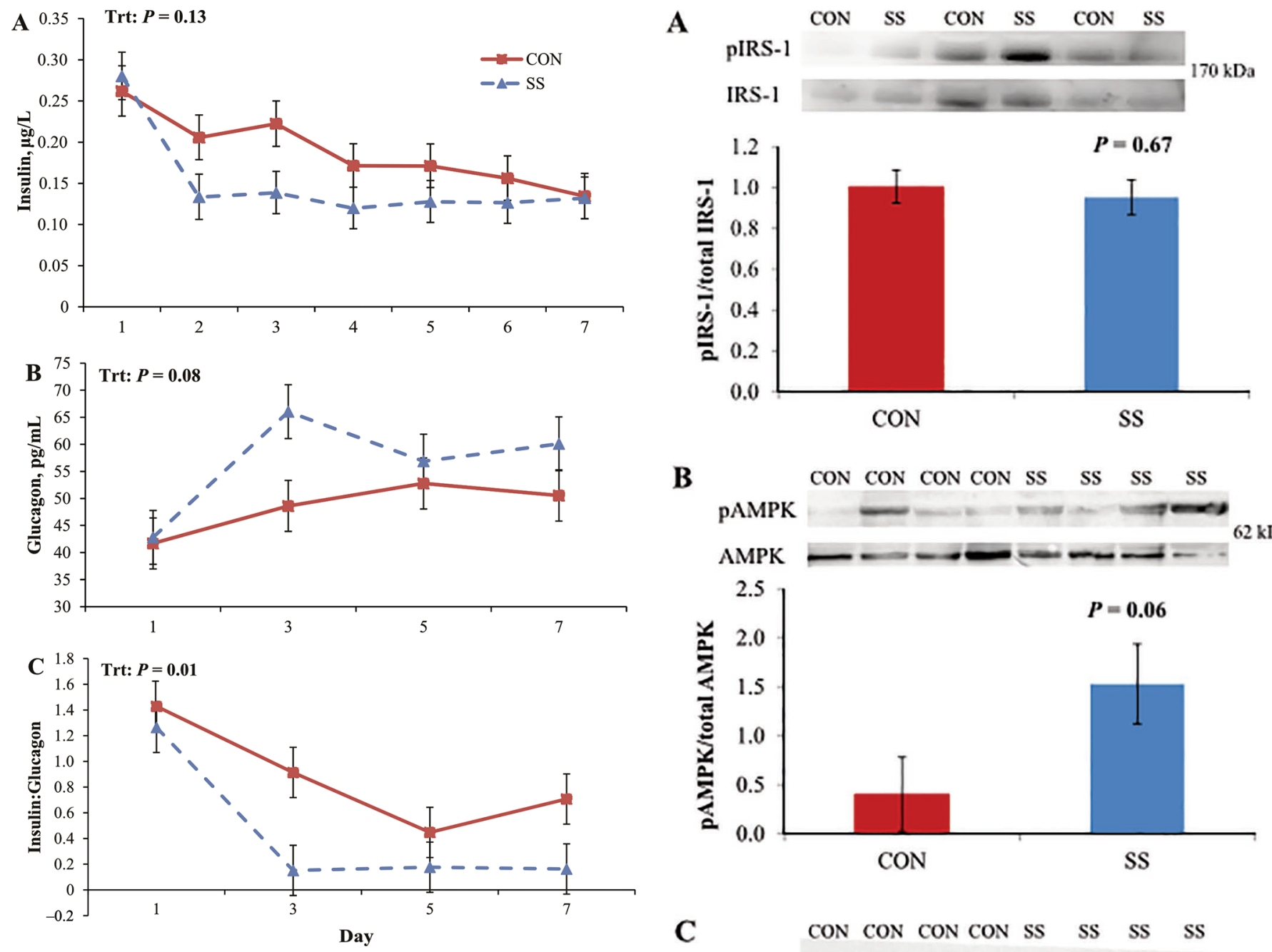

Figure 3. Postpartum plasma insulin, glucagon, and insulin: glucagon molar ratio responses to treatment. Treatment with $2.3 \mathrm{~g} / \mathrm{L}$ of sodium salicylate in drinking water $(\mathrm{SS})$ or control $(\mathrm{CON})$ began approximately $24 \mathrm{~h}$ after calving and continued through d 7 of lactation. (A) Insulin concentrations were not affected by treatment $(P$ $=0.13$; treatment $\times$ day, $P=0.25$ ). (B) Glucagon, a hormone that stimulates gluconeogenesis, tended to be increased in SS cows $(P=$ 0.08 ; treatment $\times$ day, $P=0.32$ ). (C) The insulin:glucagon molar ratio was decreased by SS $(P=0.01$; treatment $\times$ day, $P=0.30)$. Values are $\mathrm{LSM} \pm \mathrm{SEM} ; \mathrm{n}=8-10$. Trt $=$ treatment

Plasma haptoglobin, the most heavily used biomarker of inflammation in transition cows, had a mean concentration of $510 \mu \mathrm{g} / \mathrm{mL}$ at $5 \mathrm{DIM}$ in this cohort, similar to the median value of $640 \mu \mathrm{g} / \mathrm{mL}$ across 412 cows on 2 commercial farms (Huzzey et al., 2015). However, as in previous work (Carpenter et al., 2016, 2018), salicylate did not decrease plasma haptoglobin concentration or most other biomarkers of inflammatory status (Tables 4 and 5). Nevertheless, salicylate administration clearly influences systemic metabolism in this scenario. It may do so via mechanisms that do not rely on its anti-

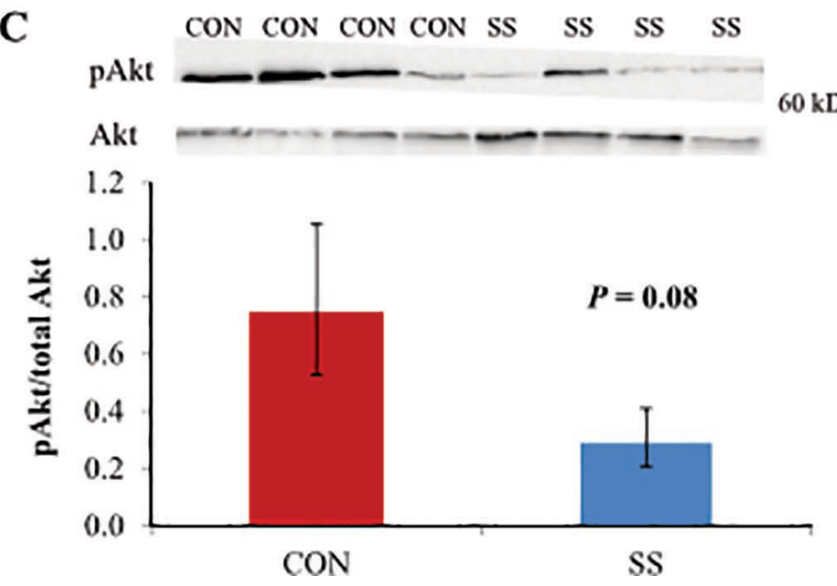

Figure 4. Postpartum (d 7) adipose tissue relative phosphorylation (p) of insulin receptor substrate 1 (IRS-1), AMP-activated protein kinase (AMPK), and protein kinase B (Akt) in response to treatment. Treatment with $2.3 \mathrm{~g} / \mathrm{L}$ of sodium salicylate in drinking water (SS) or control (CON) began approximately $24 \mathrm{~h}$ after calving and continued through $d 7$ of lactation. Values are LSM \pm SEM; $n=8-10$. 
inflammatory properties, but it is also possible that the biomarkers commonly measured in transition cows overlook the signals (or organs) that are most affected by salicylate. Another possibility we discussed previously (Farney et al., 2013a) is that homeostatic mechanisms may be at work to maintain inflammatory tone even in the face of exogenous anti-inflammatory agents. Unfortunately, the current study does not resolve the question of whether the effects of salicylate in transition cows are independent of its anti-inflammatory role.

In previous work, postpartum treatment of cows with SS induced clear hypoglycemia and evidence of enhanced insulin sensitivity, particularly in cows of parity 3 and greater (Farney et al., 2013a). We hypothesized that this response could be due to enhanced insulin sensitivity, either in hepatic or peripheral tissues, and the current study was designed to address this hypothesis. In this study we did not observe significant differences in plasma glucose concentrations. Treatment dose, water intake, and DMI were similar between these 2 experiments, so it is difficult to explain why the response was more subtle in this study. Nevertheless, the SS-induced decrease in insulin:glucagon ratio strongly suggests either a direct effect of SS on hormone release or a compensated glucose deficiency with this treatment. In either case, the overall metabolic profile changed in a manner similar to that observed during the treatment window by Farney et al. (2013a). We also note that, although we have previously reported dramatic increases in milk yield following SS treatment (Farney et al., 2013b; Carpenter et al., 2016), the milk response was consistently delayed by 4 to 6 wk with no response during treatment. Because of the very invasive nature of the current study and the limited statistical power for productivity outcomes, we did not monitor longer-term milk yield responses in this case.
High concentrations of circulating fatty acids can induce IR (Boden, 1997). Abundant fatty acids can cause accumulation of fatty acid metabolites such as ceramides, which activate the serine/threonine kinase cascade, leading to serine phosphorylation and subsequent inhibition of signal transduction by insulin receptor substrates (IRS-1 and IRS-2; Shulman, 2000; Rico et al., 2018). In muscle and adipose tissue, the inhibition of IRS-1 and IRS-2 signaling leads to a decrease in insulin-dependent glucose transport via GLUT4, contributing to IR. Although no change in GLUT4 transcript abundance was observed, the phosphorylation of Akt in adipose tissue tended to be inhibited by SS, which may indicate reduced insulin signaling, through decreased insulin concentrations, responsiveness, or both. Similar tissue-specific responses were observed by Zachut et al. (2013), in which adipose showed decreased insulin sensitivity, whereas whole-body responsiveness to insulin was not altered. Hence, we suggest that SS treatment may cause a local reduction in insulin sensitivity in adipose tissue, while at the same time maintaining whole-body insulin sensitivity.

Glucose turnover rate is a proxy for gluconeogenesis in the cow because net portal appearance of glucose is minimal (Reynolds et al., 1988). Steady-state assumptions are required for these methods, meaning that any glucose leaving the system has to be replaced instantaneously (glucose in = glucose out). These assumptions were supported by feeding small, consistent meals in the hours before glucose turnover measurement, and we verified that plasma glucose concentrations were stable during the measurement window. Therefore, the tendency for a change in glucose turnover suggests that both entry and removal of plasma glucose decreased in response to SS treatment. This response could be explained either by a primary inhibition of gluconeogene-

Table 5. Transcript abundance responses to $7 \mathrm{~d}$ of postpartum treatment with sodium salicylate $(2.3 \mathrm{~g} / \mathrm{L}$ in drinking water)

\begin{tabular}{llccc}
\hline Tissue & Transcript & $\begin{array}{c}\text { Relative mRNA } \\
\text { abundance }\end{array}$ & $95 \%$ CI & $P$-value \\
\hline Muscle & TNFA & 0.87 & $0.44,1.72$ & 0.77 \\
& HSD11B1 & 1.27 & $0.39,4.17$ & 0.77 \\
GLUT4 & 0.83 & $0.49,1.41$ & 0.63 \\
Adipose & PPARGC1A & 0.48 & $0.18,1.29$ & 0.30 \\
& TNFA & 0.37 & $0.16,0.85$ & 0.09 \\
Liver & HSD11B1 & 1.16 & $0.32,4.29$ & 0.87 \\
& GLUT4 & 1.33 & $0.79,1.86$ & 0.39 \\
& TNFA & 0.58 & $0.16,2.03$ & 0.54 \\
& HSD11B1 & 1.11 & $0.04,28.32$ & 0.96 \\
& GLUT4 & 0.91 & $0.19,4.46$ & 0.93 \\
& G6PC & 1.31 & $0.20,8.71$ & 0.84 \\
& PPARGC1A & 0.82 & $0.19,3.49$ & 0.84 \\
\hline
\end{tabular}

${ }^{1}$ Relative abundance for SS treatment where $\mathrm{CON}=1 ; \mathrm{n}=8-9$. 
sis, or perhaps by a decrease in systemic use of glucose, resulting in secondary inhibition of gluconeogenesis. However, this secondary inhibition of gluconeogenesis would almost certainly be signaled in part through increased insulin secretion, decreased glucagon secretion, or both. In light of the decreased insulin:glucagon ratio in response to SS without an increase in plasma glucose concentration, the change in glucose turnover most likely reflects a primary effect of SS on gluconeogenesis and a secondary effect on glucose removal, rather than the other way around.

Insulin inhibits gluconeogenesis, so an increased hepatic response to insulin could explain why the glucose turnover rate tended to decrease by $25 \%$. Indeed, salicylate has consistently suppressed hepatic glucose production and enhanced insulin suppression of gluconeogenesis in rodent models (Ford et al., 2015). One mechanism of SS is to impair the ability of IKK- $\beta$ to activate the NF- $\kappa \mathrm{B}$ inflammatory pathway (Yin et al., 1998). Arkan et al. (2005) also linked IKK- $\beta$ to IR. Therefore, SS, which hinders IKK- $\beta$ activity, may also increase insulin sensitivity. This has been confirmed by a variety of reports in obese or diabetic rats, mice, and humans (Kim et al., 2001; Yuan et al., 2001; Hundal et al., 2002; Park et al., 2007). However, insulin inhibits the expression of pro-gluconeogenic enzymes PGC1a and G6P (Barthel and Schmoll, 2003; Puigserver et al., 2003), and the lack of treatment effect on abundance of these transcripts in the current study casts some doubt on an insulin sensitivity mechanism underlying the apparent shift in glucose production. Mamedova et al. (2013) found evidence that inflammatory signaling through toll-like receptor 4 promoted gluconeogenic gene expression in human hepatocellular carcinoma cells, independent of insulin signaling mechanisms. If inflammation increases gluconeogenesis, it is plausible that treatment with an anti-inflammatory agent would suppress gluconeogenesis.

Another mechanism that could account for posttranscriptional alterations in glucose metabolism is the ability of SS to activate AMPK (Hawley et al., 2012). When activated, AMPK promotes catabolic (ATPgenerating) processes, such as fatty acid oxidation and glucose uptake, and inhibits anabolic (ATP-consuming) processes such as gluconeogenesis (Hardie, 2008). In the short term, AMPK alters protein function, including activation of GLUT4 transporters and deactivation of gluconeogenic enzymes, and only alters gene expression in the long term (Hardie, 2008). Rainsford (2004) suggested that SS treatment increased the conversion of pyruvate to lactate because the creation of glucose from pyruvate was inhibited by AMPK activation; however, we did not detect any treatment effect on plasma lactate concentration in the current study. In the pres- ent study we found a tendency for increased AMPK phosphorylation in adipose tissues of SS versus control cows, which may support the premise that SS increases AMPK activation in vivo. Interestingly, AMPK activation has been shown to suppress multiple pro-inflammatory pathways, such as TNFo-stimulated IKK/IкB/ NFkB signaling, in cultured adipocytes (Mancini et al., 2017); in agreement with this, we found that TNFA mRNA abundance in adipose tended to be decreased in SS cows. On the other hand, AKT phosphorylation of adipose tissue (an insulin signaling mediator) tended to be lower in SS than in controls. Activation of AMPK has been linked to insulin sensitivity, although the exact mechanism for this is unknown (Ruderman et al., 2003); hence, the altered insulin signaling coupled with increased AMPK activation in adipose of SS treated cows warrants further investigation.

The plasma adiponectin concentrations in the present study are comparable to those reported by Kafi et al. (2015) at $1 \mathrm{wk}$ postpartum but were only $25 \%$ of the concentrations reported by Singh et al. (2014a) at $1 \mathrm{wk}$ after calving. This difference in adiponectin concentrations may be due differences in metabolic status. Adiponectin, an adipokine, plays a role in the regulation of glucose and lipid metabolism (Yamauchi et al., 2001, 2002; Zhou et al., 2005; Singh et al., 2014b). Yamauchi et al. (2001) showed that low circulating concentrations of adiponectin in mice were associated with IR and that treatment with adiponectin enhanced insulin sensitivity. Circulating adiponectin levels in dairy cattle are least right after calving (Giesy et al., 2012; Singh et al., 2014a), highlighting the possibility that low plasma adiponectin may be a contributing factor to diminished insulin sensitivity in periparturent dairy cattle. In fact, Singh et al. (2014a) speculated that the combination of IR in peripheral tissue and decreasing levels of plasma adiponectin around parturition may facilitate the funneling of glucose to the mammary gland. In this current study, however, there was no difference in plasma adiponectin concentrations between treatments, indicating that any change in insulin sensitivity among SS-treated cows was not likely driven by adiponectin.

Recently, Cameron et al. (2016) published an indepth investigation of several possible modes of action for salicylate's effect on hepatic function. These experiments confirmed that SS activates AMPK, inhibits $\mathrm{NF} \kappa \mathrm{B}$ activation, and induces metabolic uncoupling simultaneously with inhibition of gluconeogenesis. Importantly, though, in dose-response experiments, none of these effects were observed at salicylate concentrations $<1 \mathrm{mM}$ (Cameron et al., 2016). Most in vivo and in vitro studies investigating salicylate inhibition of gluconeogenesis have used concentrations of 0.8 to 30 mM (Kim et al., 2001; Hawley et al., 2012; Smith et al., 
2016), and to our knowledge, metabolic responses have not been reported at concentrations less than $0.25 \mathrm{mM}$ (Smith et al., 2016). The treatment protocol used in the current study resulted in a mean plasma salicylate concentration of just $34 \mu \mathrm{g} / \mathrm{mL}$, which equates to $0.25 \mathrm{mM}$ (Farney et al., 2013a). Based on the findings of Smith et al. (2016) in comparison to dose-responses of Cameron et al. (2016), perhaps the most likely mode of action for the effect of SS on hepatic metabolism is mitochondrial uncoupling, resulting in decreased ATP concentrations and AMPK activation, and in turn, enhanced insulin signaling. Nevertheless, other data directly contradict this model (Ford et al., 2015). The confusion around salicylate's mode of action may ultimately be due to its multiple, overlapping effects (Cameron et al., 2016).

Finally, a pre-absorptive mechanism for salicylate's effect on gluconeogenesis must also be considered. We reported previously that salicylate decreased both in vivo and in vitro fermentation, assessed by substrate disappearance (Carpenter et al., 2017). In these investigations, we did not determine VFA profiles, but assuming that propionate production was decreased proportionally with the amount of DM fermented, its supply would have been decreased. Therefore, it is possible that SS decreased propionate flux to the liver in the current study, potentially constraining gluconeogenic flux because of inadequate supply of the primary substrate for gluconeogenesis in the cow (Larsen and Kristensen, 2013). Unfortunately, the current study was not designed to discriminate between insulin-mediated and substrate constraints on metabolic flux, as it was carried out before the findings of fermentative inhibition by salicylate. Ongoing work employing direct in vivo measures of insulin responsiveness will help to determine the key mechanism underlying changes in glucose metabolism in response to relatively low-dose salicylate treatments in lactating cows.

\section{CONCLUSIONS}

We explored the role of inflammatory signaling in glucose and energy metabolism of early lactation dairy cattle. Treatment with the nonsteroidal antiinflammatory drug SS tended to suppress whole-body glucose turnover in mature transition cows, perhaps necessitating the tendency for decreased Akt signaling downstream of the insulin receptor in adipose tissue to adapt to the limited glucose supply without inhibiting milk production. Salicylate may have altered gluconeogenic capacity, but no effects on mRNA abundance for rate-determining enzymes in gluconeogenesis were observed. Salicylate also may have inhibited ruminal propionate production, limiting gluconeogenesis by limited substrate supply. Additional research is needed to discriminate among these potential modes of action and better understand how inflammatory signaling may contribute to changes in insulin signaling in postpartum dairy cattle.

\section{ACKNOWLEDGMENTS}

This is contribution no. 18-497-J from the Kansas Agricultural Experiment Station (Manhattan). The authors thank Mike Scheffel (Manhattan, KS) and Kansas State University graduate and undergraduate students for their assistance in sample collection and analysis.

\section{REFERENCES}

Arkan, M. C., A. L. Hevener, F. R. Greten, S. Maeda, Z. Li, J. M. Long, A. Wynshaw-Boris, G. Poli, J. Olefsky, and M. Karin. 2005. IKK- $\beta$ links inflammation to obesity-induced insulin resistance. Nat. Med. 11:191-198.

Baker, R. G., M. S. Hayden, and S. Ghosh. 2011. NF-кB, inflammation, and metabolic disease. Cell Metab. 13:11-22.

Barthel, A., and D. Schmoll. 2003. Novel concepts in insulin regulation of hepatic gluconeogenesis. Am. J. Physiol. Endocrinol. Metab. 285:E685-E692.

Baumgard, L. H., R. J. Collier, and D. E. Bauman. 2017. A 100-Year Review: Regulation of nutrient partitioning to support lactation. J. Dairy Sci. 100:10353-10366. https://doi.org/10.3168/jds.2017 $-13242$.

Bland, J. M., and D. G. Altman. 1996. Statistics notes: Transformations, means, and confidence intervals. BMJ 312:1079.

Boden, G. 1997. Role of fatty acids in the pathogenesis of insulin resistance and NIDDM. Diabetes 46:3-10.

Bradford, B. J., K. Yuan, J. K. Farney, L. K. Mamedova, and A. J. Carpenter. 2015. Invited Review: Inflammation during the transition to lactation: New adventures with an old flame. J. Dairy Sci. 98:6631-6650.

Cameron, A. R., L. Logie, K. Patel, S. Bacon, C. Forteath, J. Harthill, A. Roberts, C. Sutherland, D. Stewart, B. Viollet, K. Sakamoto, G. McDougall, M. Foretz, and G. Rena. 2016. Investigation of salicylate hepatic responses in comparison with chemical analogues of the drug. Biochim. Biophys. Acta 1862:1412-1422. https://doi .org/10.1016/j.bbadis.2016.04.015.

Carpenter, A. J., C. F. V. Rodriguez, J. A. B. Jantz, and B. J. Bradford. 2017. Short communication: Sodium salicylate negatively affects rumen fermentation in vitro and in situ. J. Dairy Sci. 100:1935-1939. https://doi.org/10.3168/jds.2016-11832.

Carpenter, A. J., C. M. Ylioja, L. K. Mamedova, K. E. Olagaray, and B. J. Bradford. 2018. Effects of early postpartum sodium salicylate treatment on long-term milk, intake, and blood parameters of dairy cows. J. Dairy Sci. 101:1437-1447. https://doi.org/10.3168/ jds.2017-13057.

Carpenter, A. J., C. M. Ylioja, C. F. Vargas, L. K. Mamedova, L. G. Mendonca, J. F. Coetzee, L. C. Hollis, R. Gehring, and B. J. Bradford. 2016. Hot topic: Early postpartum treatment of commercial dairy cows with nonsteroidal antiinflammatory drugs increases whole-lactation milk yield. J. Dairy Sci. 99:672-679. https://doi .org/10.3168/jds.2015-10048.

Contreras, G. A., and L. M. Sordillo. 2011. Lipid mobilization and inflammatory responses during the transition period of dairy cows. Comp. Immunol. Microbiol. Infect. Dis. 34:281-289.

Cooke, R. F., and J. D. Arthington. 2013. Concentrations of haptoglobin in bovine plasma determined by ELISA or a colorimetric method based on peroxidase activity. J. Anim. Physiol. Anim. Nutr. (Berl.) 97:531-536.

Drackley, J. K. 1999. Biology of dairy cows during the transition period: The final frontier? J. Dairy Sci. 82:2259-2273. 
Farney, J. K., L. K. Mamedova, J. F. Coetzee, B. Kukanich, L. M. Sordillo, S. K. Stoakes, J. E. Minton, L. C. Hollis, and B. J. Bradford. 2013a. Anti-inflammatory salicylate treatment alters the metabolic adaptations to lactation in dairy cattle. Am. J. Physiol. Regul. Integr. Comp. Physiol. 305:R110-R117.

Farney, J. K., L. K. Mamedova, J. F. Coetzee, J. E. Minton, L. C. Hollis, and B. J. Bradford. 2013b. Sodium salicylate treatment in early lactation increases whole-lactation milk and milk fat yield in mature dairy cows. J. Dairy Sci. 96:7709-7718.

Farney, J. K., L. K. Mamedova, B. H. Godsey, and B. J. Bradford. 2011. Technical note: Validation of an ELISA for measurement of tumor necrosis factor alpha in bovine plasma. J. Dairy Sci. 94:3504-3509.

Ford, R. J., M. D. Fullerton, S. L. Pinkosky, E. A. Day, J. W. Scott, J. S. Oakhill, A. L. Bujak, B. K. Smith, J. D. Crane, R. M. Blümer, K. Marcinko, B. E. Kemp, H. C. Gerstein, and G. R. Steinberg. 2015. Metformin and salicylate synergistically activate liver AMPK, inhibit lipogenesis and improve insulin sensitivity. Biochem. J. 468:125-132. https://doi.org/10.1042/BJ20150125.

Giesy, S. L., B. Yoon, W. B. Currie, J. W. Kim, and Y. R. Boisclair 2012. Adiponectin deficit during the precarious glucose economy of early lactation in dairy cows. Endocrinology 153:5834-5844.

Gordon, J. L., S. J. LeBlanc, D. F. Kelton, T. H. Herdt, L. Neuder, and T. F. Duffield. 2017. Randomized clinical field trial on the effects of butaphosphan-cyanocobalamin and propylene glycol on ketosis resolution and milk production. J. Dairy Sci. 100:3912-3921. https://doi.org/10.3168/jds.2016-11926.

Grummer, R. R. 1995. Impact of changes in organic nutrient metabolism on feeding the transition dairy cow. J. Anim. Sci. 73:28202833.

Hardie, D. G. 2008. AMPK: A key regulator of energy balance in the single cell and the whole organism. Int. J. Obes. (Lond.) 32:S7S12.

Hawley, S. A., M. D. Fullerton, F. A. Ross, J. D. Schertzer, C. Chevtzoff, K. J. Walker, M. W. Peggie, D. Zibrova, K. A. Green, K. J. Mustard, B. E. Kemp, K. Sakamoto, G. R. Steinberg, and D. G. Hardie. 2012. The ancient drug salicylate directly activates AMPactivated protein kinase. Science 336:918-922.

Hotamisligil, G. S. 2010. Endoplasmic reticulum stress and the inflammatory basis of metabolic disease. Cell 140:900-917.

Humblet, M. F., H. Guyot, B. Boudry, F. Mbayahi, C. Hanzen, F. Rollin, and J. M. Godeau. 2006. Relationship between haptoglobin, serum amyloid A, and clinical status in a survey of dairy herds during a 6-month period. Vet. Clin. Pathol. 35:188-193.

Hundal, R. S., K. F. Petersen, A. B. Mayerson, P. S. Randhawa, S. Inzucchi, S. E. Shoelson, and G. I. Shulman. 2002. Mechanism by which high-dose aspirin improves glucose metabolism in type 2 diabetes. J. Clin. Invest. 109:1321-1326.

Huzzey, J. M., S. Mann, D. V. Nydam, R. J. Grant, and T. R. Overton. 2015. Associations of peripartum markers of stress and inflammation with milk yield and reproductive performance in Holstein dairy cows. Prev. Vet. Med. 120:291-297. https://doi.org/10.1016/ j.prevetmed.2015.04.011.

Ingvartsen, K. L. 2006. Feeding- and management-related diseases in the transition cow. Anim. Feed Sci. Technol. 126:175-213.

Kafi, M., A. Tamadon, and M. Saeb. 2015. The relationship between serum adiponectin and postpartum luteal activity in high-producing dairy cows. Theriogenology 83:1264-1271.

Kim, J. K., Y. J. Kim, J. J. Fillmore, Y. Chen, I. Moore, J. Lee, M. Yuan, Z. W. Li, M. Karin, P. Perret, S. E. Shoelson, and G. I. Shulman. 2001. Prevention of fat-induced insulin resistance by salicylate. J. Clin. Invest. 108:437-446.

Larsen, M., and N. B. Kristensen. 2013. Precursors for liver gluconeogenesis in periparturient dairy cows. Animal 7:1640-1650. https:// doi.org/10.1017/S1751731113001171.

Lucy, M. C., S. T. Butler, and H. A. Garverick. 2014. Endocrine and metabolic mechanisms linking postpartum glucose with early embryonic and foetal development in dairy cows. Animal 8:82-90. https://doi.org/10.1017/S1751731114000482.

Mamedova, L. K., K. Yuan, A. N. Laudick, S. D. Fleming, D. G. Mashek, and B. J. Bradford. 2013. Toll-like receptor 4 signal- ing is required for induction of gluconeogenic gene expression by palmitate in human hepatic carcinoma cells. J. Nutr. Biochem. 24:1499-1507.

Mancini, S. J., A. D. White, S. Bijland, C. Rutherford, D. Graham, E. A. Richter, B. Viollet, R. M. Touyz, T. M. Palmer, and I. P. Salt. 2017. Activation of AMP-activated protein kinase rapidly suppresses multiple pro-inflammatory pathways in adipocytes including IL-1 receptor-associated kinase-4 phosphorylation. Mol Cell. Endocrinol. 440:44-56. https://doi.org/10.1016/j.mce.2016 .11 .010 .

Mielenz, M., B. Mielenz, S. P. Singh, C. Kopp, J. Heinz, S. Haussler, and H. Sauerwein. 2013. Development, validation, and pilot application of a semiquantitative Western blot analysis and an ELISA for bovine adiponectin. Domest. Anim. Endocrinol. 44:121-130.

Morey, S. D., L. K. Mamedova, D. E. Anderson, C. K. Armendariz, E. C. Titgemeyer, and B. J. Bradford. 2011. Effects of encapsulated niacin on metabolism and production of periparturient dairy cows. J. Dairy Sci. 94:5090-5104.

Morino, K., K. F. Petersen, and G. I. Shulman. 2006. Molecular mechanisms of insulin resistance in humans and their potential links with mitochondrial dysfunction. Diabetes 55(S2):S9-S15.

Mulligan, F. J., and M. L. Doherty. 2008. Production diseases of the transition cow. Vet. J. 176:3-9.

Nixon, M., D. J. Wake, D. E. Livingstone, R. H. Stimson, C. L. Esteves, J. R. Seckl, K. E. Chapman, R. Andrew, and B. R. Walker. 2012. Salicylate downregulates 11beta-HSD1 expression in adipose tissue in obese mice and in humans, mediating insulin sensitization. Diabetes 61:790-796. https://doi.org/10.2337/db11-0931.

Park, E., V. Wong, X. Guan, A. I. Oprescu, and A. Giacca. 2007. Salicylate prevents hepatic insulin resistance caused by short-term elevation of free fatty acids in vivo. J. Endocrinol. 195:323-331.

Pfaffl, M. W. 2001. A new mathematical model for relative quantification in real-time RT-PCR. Nucleic Acids Res. 29:e45.

Puigserver, P., J. Rhee, J. Donovan, C. J. Walkey, J. C. Yoon, F. Oriente, Y. Kitamura, J. Altomonte, H. Dong, D. Accili, and B. M. Spiegelman. 2003. Insulin-regulated hepatic gluconeogenesis through FOXO1-PGC-1 $\alpha$ interaction. Nature 423:550-555.

Rainsford, K. D. 2004. Aspirin and Related Drugs. 1st ed. Taylor \& Francis, London, UK.

Reynolds, C. K., G. B. Huntington, H. F. Tyrrell, and P. J. Reynolds. 1988. Net portal-drained visceral and hepatic metabolism of glucose, L-lactate, and nitrogenous compounds in lactating Holstein cows. J. Dairy Sci. 71:1803-1812.

Rico, J. E., W. A. Myers, D. J. Laub, A. N. Davis, Q. Zeng, and J. W. McFadden. 2018. Hot topic: Ceramide inhibits insulin sensitivity in primary bovine adipocytes. J. Dairy Sci. 101:3428-3432. https: //doi.org/10.3168/jds.2017-13983.

Ringseis, R., D. K. Gessner, and K. Eder. 2015. Molecular insights into the mechanisms of liver-associated diseases in early-lactating dairy cows: Hypothetical role of endoplasmic reticulum stress. J. Anim. Physiol. Anim. Nutr. (Berl.) 99:626-645. https://doi.org/ 10.1111/.jpn.12263.

Ruderman, N. B., J. M. Cacicedo, S. Itani, N. Yagihashi, A. K. Saha, J. M. Ye, K. Chen, M. Zou, D. Caring, G. Boden, R. A. Cohen, J. Keaney, E. W. Kraegen, and Y. Ido. 2003. Malonyl-CoA and AMP-activated protein kinase (AMPK): Possible links between insulin resistance in muscle and early endothelial cell damage in diabetes. Biochem. Soc. Trans. 31:202-206.

Schukken, Y. H., D. J. Wilson, F. Welcome, L. Garrison-Tikofsky, and R. N. Gonzalez. 2003. Monitoring udder health and milk quality using somatic cell counts. Vet. Res. 34:579-596.

Shulman, G. I. 2000. Cellular mechanisms of insulin resistance. J. Clin. Invest. 106:171-176.

Singh, S. P., S. Haussler, J. J. Gross, F. J. Schwarz, R. M. Bruckmaier, and H. Sauerwein. 2014a. Short communication: Circulating and milk adiponectin change differently during energy deficiency at different stages of lactation in dairy cows. J. Dairy Sci. 97:1535-1542.

Singh, S. P., S. Haussler, J. F. L. Heinz, B. Saremi, B. Mielenz, J. Rehage, S. Danicke, M. Mielenz, and H. Sauerwein. 2014b. Supplementation with conjugated linoleic acids extends the adiponectin 
deficit during early lactation in dairy cows. Gen. Comp. Endocrinol. 198:13-21.

Smith, B. K., R. J. Ford, E. M. Desjardins, A. E. Green, M. C. Hughes, V. P. Houde, E. A. Day, K. Marcinko, J. D. Crane, E. P. Mottillo, C. G. R. Perry, B. E. Kemp, M. A. Tarnopolsky, and G. R. Steinberg. 2016. Salsalate (salicylate) uncouples mitochondria, improves glucose homeostasis, and reduces liver lipids independent of AMPK-B1. Diabetes 65:3352-3361. https://doi.org/10.2337/ db16-0564.

Sordillo, L. M., G. A. Contreras, and S. L. Aitken. 2009. Metabolic factors affecting the inflammatory response of periparturient dairy cows. Anim. Health Res. Rev. 10:53-63.

Sordillo, L. M., and W. Raphael. 2013. Significance of metabolic stress, lipid mobilization, and inflammation on transition cow disorders. Vet. Clin. North Am. Food Anim. Pract. 29:267-278.

Tserng, K. Y., and S. C. Kalhan. 1983. Estimation of glucose carbon recycling and glucose turnover with [U-13C] glucose. Am. J. Physiol. 245:E476-E482.

Vernon, R. G., A. Faulkner, W. W. Hay Jr., D. T. Calvert, and D. J. Flint. 1990. Insulin resistance of hind-limb tissues in vivo in lactating sheep. Biochem. J. 270:783-786.

Vernon, R. G., and E. Finley. 1988. Roles of insulin and growth hormone in the adaptations of fatty acid synthesis in white adipose tissue during the lactation cycle in sheep. Biochem. J. 256:873878. https://doi.org/10.1042/bj2560873.

Waldron, M. R., A. E. Kulick, A. W. Bell, and T. R. Overton. 2006. Acute experimental mastitis is not causal toward the development of energy-related metabolic disorders in early postpartum dairy cows. J. Dairy Sci. 89:596-610.

Weber, C., C. T. Schaff, U. Kautzsch, S. Borner, S. Erdmann, S. Gors, M. Rontgen, H. Sauerwein, R. M. Bruckmaier, C. C. Metges, B. Kuhla, and H. M. Hammon. 2016. Insulin-dependent glucose metabolism in dairy cows with variable fat mobilization around calving. J. Dairy Sci. 99:6665-6679. https://doi.org/10.3168/jds .2016-11022.

Yamauchi, T., J. Kamon, Y. Minokoshi, Y. Ito, H. Waki, S. Uchida, S. Yamashita, M. Noda, S. Kita, K. Ueki, K. Eto, Y. Aranuma, P. Froguel, F. Foufelle, P. Ferre, D. Carling, S. Kimura, R. Nagai, B. B. Kahn, and T. Kadowaki. 2002. Adiponectin stimulates glucose utilization and fatty-acid oxidation by activating AMP-activated protein kinase. Nat. Med. 8:1288-1295.

Yamauchi, T., J. Kamon, H. Waki, Y. Terauchi, N. Kubota, K. Hara, Y. Mori, T. Ide, K. Murakami, N. Tsuboyama-kasaoka, O. Ezaki, Y. Akanuma, O. Gavrilova, C. Vinson, M. L. Reitman, H. Kagechika, K. Shudo, M. Yoda, Y. Nakano, K. Tobe, R. Nagai, S. Kimura, M. Tomita, P. Froguel, and T. Kadowaki. 2001. The fatderived hormone adiponectin reverses insulin resistance associated with both lipoatrophy and obesity. Nat. Med. 7:941-946.

Yin, M. J., Y. Yamamoto, and R. B. Gaynor. 1998. The anti-inflammatory agents aspirin and salicylate inhibit the activity of I(kappa)B kinase-beta. Nature 396:77-80.

Yuan, M., N. Konstantopoulos, J. Lee, L. Hansen, Z. W. Li, M. Karin, and S. E. Shoelson. 2001. Reversal of obesity- and diet-induced insulin resistance with salicylates or targeted disruption of IKKbeta. Science 293:1673-1677.

Zachut, M., H. Honig, S. Striem, Y. Zick, S. Boura-Halfon, and U. Moallem. 2013. Periparturient dairy cows do not exhibit hepatic insulin resistance, yet adipose-specific insulin resistance occurs in cows prone to high weight loss. J. Dairy Sci. 96:5656-5669. https: //doi.org/10.3168/jds.2012-6142.

Zhou, H., X. Song, M. Briggs, B. Violand, W. Salsgiver, E. A. Gulve, and Y. Luo. 2005. Adiponectin represses gluconeogenesis independent of insulin in hepatocytes. Biochem. Biophys. Res. Commun. 338:793-799. 